\title{
Correction to: How will a drier climate change carbon sequestration in soils of the deciduous forests of Central Europe?
}

\author{
István Fekete · Imre Berki - Kate Lajtha · Susan Trumbore • Ornella Francioso • \\ Paola Gioacchini · Daniela Montecchio · Gábor Várbíró · Áron Béni · \\ Marianna Makádi · Ibolya Demeter · Balázs Madarász • Katalin Juhos • \\ Zsolt Kotroczó
}

Published online: 18 December 2020

(C) The Author(s) 2020

\section{Correction to: \\ Biogeochemistry \\ https://doi.org/10.1007/s10533-020-00728-w}

The initial online publication contained a typesetting mistake in the author information. The original article has been corrected.

The original article can be found online at https:// doi.org/10.1007/s10533-020-00728-w.

\footnotetext{
I. Fekete $(\bowtie)$

Institute of Environmental Sciences, University of

Nyíregyháza, Nyíregyháza, Hungary

e-mail: feketeistani@gmail.com
}

I. Fekete · K. Juhos · Z. Kotroczó (ه)

Department of Soil Science and Water Management,

Szent István University, Budapest, Hungary

e-mail: kotroczo.zsolt@gmail.com

I. Berki

Institute of Environmental and Earth Sciences, University of Sopron Hungary, Sopron, Hungary

K. Lajtha

Department of Crop and Soil Sciences, Oregon State

University, Corvallis, OR, USA

S. Trumbore

Max Planck Institute for Biogeochemistry, Jena, Germany
Open Access This article is licensed under a Creative Commons Attribution 4.0 International License, which permits use, sharing, adaptation, distribution and reproduction in any medium or format, as long as you give appropriate credit to the original author(s) and the source, provide a link to the Creative Commons licence, and indicate if changes were made. The images or other third party material in this article are included in the article's Creative Commons licence, unless indicated otherwise in a credit line to the material. If material is not included in the article's Creative Commons licence and your

\author{
O. Francioso - P. Gioacchini · D. Montecchio \\ Department of Agricultural and Food Sciences, University \\ of Bologna, Bologna, Italy \\ G. Várbíró \\ Department of Tisza River Research, Danube Research \\ Institute, Centre for Ecology of HAS, Debrecen, Hungary \\ Á. Béni \\ Institute of Agricultural Chemistry and Soil Science, \\ University of Debrecen, Debrecen, Hungary \\ M. Makádi · I. Demeter \\ Centre for Agricultural Sciences, Research Institute of \\ Nyíregyháza, University of Debrecen, Nyíregyháza, \\ Hungary \\ B. Madarász \\ Geographical Institute, Research Centre for Astronomy \\ and Earth Sciences, Budapest, Hungary
}


intended use is not permitted by statutory regulation or exceeds the permitted use, you will need to obtain permission directly from the copyright holder. To view a copy of this licence, visit http://creativecommons.org/licenses/by/4.0/.
Publisher's Note Springer Nature remains neutral with regard to jurisdictional claims in published maps and institutional affiliations. 